\title{
The Political Struggle for Evenkia's "Special Status" Within Krasnoyarsk Krai (Central Siberia)
}

\author{
Natalia P. Koptseva, Kseniya V. Reznikova Vladimir I. Kirko
}

The article discusses the postcolonial (i.e. post-Soviet) transformations that have occurred among Central Siberia's indigenous groups. Ethnic identification processes among the Central Siberian Evenks, in particular, were on the rise during the Soviet period. The ethnic communities of Evenkia are now undergoing active stratification, with the emergence of a political elite known as "professional aborigines." This political elite is more likely to include people with mixed backgrounds residing in urbanized settlements rather than pure Evenks living a nomadic lifestyle. "Professional aborigines" have clearly identifiable economic interests characteristic of the postSoviet market economy, including high corruption rates identified with so- called "state capture."

В статье рассматриваются пост-колониальные (то есть пост-советские) трансформации, имевшие место в среде групп коренного населения Центральной Сибири. Так, в частности, в среде Эвенков Центральной Сибири, в Советский период происходили активные процессы этнической идентификации. В настоящее время этнические сообщества Эвенкии переживают период активной стратификации, наблюдается процесс появления политически активной элиты, известной как «профессиональные аборигены». Эта политическая элита включает людей смешанного происхождения, проживающих в поселках городского типа, а не этнических эвенков, ведущих кочевой образ жизни. «Профессиональные аборигены» характеризуются наличием четко выраженных экономических интересов, типичных для пост-советской рыночной экономики, включая высокий уровень коррупции, идентифицируемый с так называемой «приватизацией государства».

\section{本文讨论了西伯利亚中部本土群体出现的后殖民 如 后苏联 转变 特别的是, 西伯利亚 中部鄂温克族的民族认同进程在苏联时期曾一度呈上升趋势 埃文基民族自治区内的民 族团体如今正在经历积极的社会分层，从中出现了被称为“专业原住民”的政治精英 这类精英很可能包括定居在城市且拥有不同背景的人士，而不是单纯地过着游牧生活的 鄂温克族 “专业原住民”的经济利益十分明确，它具有后苏联市场经济的特点，包括高 腐败率, 其等同于所谓的 “政府俘获”}

Key words: Central Siberia, Krasnoyarsk Krai, Evenks, postcolonial processes

Ключевые слова: Центральная Сибирь, Красноярский край, эвенки, постколониальные процессы

关键词: 西伯利亚中部, 克拉斯诺亚尔斯克边疆区，鄂温克族，埃文基民族自治区，后殖民进程

\section{Introduction}

Postcolonial processes in modem Central Siberia are what define this area's political and economic landscape today. These processes are particularly prominent in Krasnoyarsk Krai which saw three former subjects of the Russian Federation united into one in 2005. Krasnoyarsk Krai was merged with two national autonomous areas, Evenkia and Taymyr, and this occurrence helped activate significant political changes in the region. Part of the success of this unification could be attributed to a political agreement between federal and local elites on the one hand, and ethnic indigenous elites of Siberia and the North on the other hand.

Since the mid-2000s, these indigenous elites had already been actively participating in the market changes of the economy. But for the first time in Russia's post-Soviet history, they were able to see themselves as participants in genuine political change processes, since they could now provide various political forces with votes from indigenous peoples living in Evenkia, Taymyr, and 
the Turukhansk area in Krasnoyarsk Krai.

The indigenous elites of Siberia and the North used their ethnic backgrounds in order to score political and economic points for a small group of indigenous individuals that may be referred to as "professional aborigines." Between 2010 and 2015, these individuals played the special status of Evenkia as a card in their strategy for obtaining desired privileges from the state for big businesses operating in Central Siberia's indigenous settlements. This "Evenkia special status movement" is an important element in understanding the postcolonial and post-Soviet processes occurring in Central Siberia today, where the methods and types of political struggle are significantly different from those in Central Russia, Moscow, Saint Petersburg, and the South, as well as other-non- Siberian-areas where one finds strong support for Islam.

\section{Research on the Struggles of the Native Peoples}

The political struggle of native peoples on various continents have long been the object of many academic studies: Little (2016) and Lynch (2016) in Africa; Frake (2014) and Srikanth (2014) in Asia; Fisher (2014) and Bonifacio (2013) in America, and so forth.

Many studies also look into various ethnopolitical processes as well as the struggle for special status among particular regions or peoples of Russia. For instance, the separatism of the national republics of Russia upon the collapse of the USSR has been studied by Stepanov (2000), the so-called "Tatarstan model" by Kholodov and Nuriakhmetova (2015), and the situation with the Nagaybaks by Atnagulov (2015). The latter notes that the Nagaybaks hold a complex multilevel identity in the Nagaybak area where they reside; however, due to the lack of indigenization policy governing human resources, "the political tradition of the Nagaybaks has not evolved its own quasiethnocracy" (Atnagulov, 2015, p. 144).

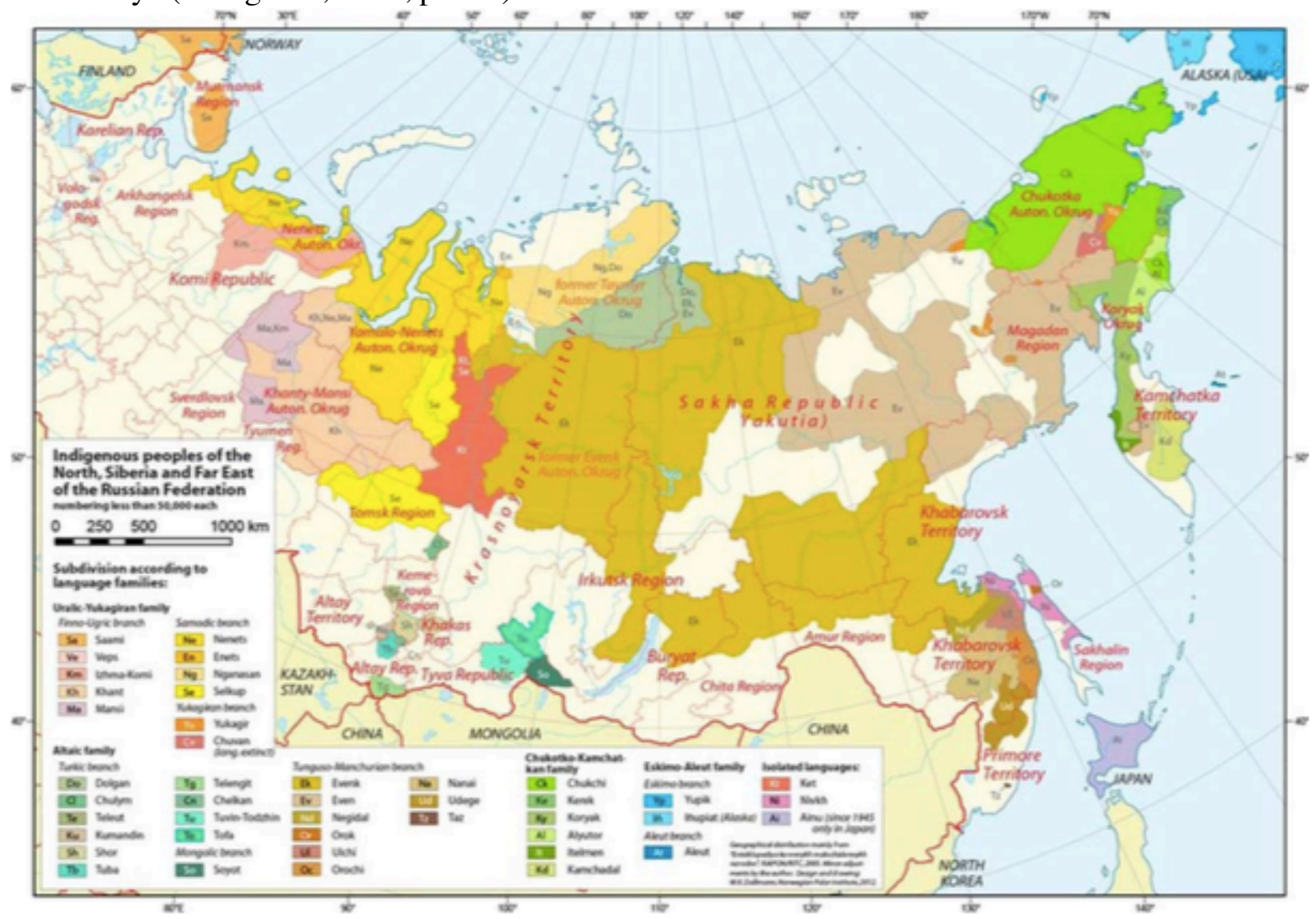

Figure 1. Maps of Indigenous People in Arctic. Indigenous Peoples of the North, Siberia and the Far East of the Russian Federation

Source: Association of Polar Early Career Scientists website. http://www.apecs.is/

The academic community takes a special interest in the ethnopolitical processes spreading across the Caucasus. Particularly notable in this respect are such authors as Sirazhudinova and 
Galbatsov (2016), Magamadov (2013), Aligadz- hieva (2016), Lobova (2002), Shirvanova (2013), Lurie (1999), and finally Boeck (1998) who views the Kuban Cossacks as a possible basis for a new nation. Changes in the ethnopolitical situation in Russia that are likely to result from the incorporation of the Crimea are, on the other hand, studied by Baranov (2015) and Kryazhkov (2014), in consideration of the Crimean Tatar movement.

Processes related to ethnic identification tend to be ethnopolitical in nature, whether they concern administrative territorial units like Evenkia, or whole regions and even whole countries. In the literature, ethnopolitical processes that go beyond the regional level to cover the whole country have been addressed by Gribanova (2015), who draws from the example of the unrecognized states within the territory of the former USSR to demonstrate that their de facto acquired sovereignty (analogous to the special status of Evenkia) has resulted in various political, economic and social issues and consequently, in the shift from separatism to irredentism - a desire to join another state (Anderson, 2006; Balzer, 2015; Holmes, 2002; Makarov, 2013; Reznikova, 2013; Zamaraeva, 2014).

According to Drobizheva (2008, pp. 225-226), striving for the special status of an ethnic administrative territorial unit reveals a lack of "positive consonance between national citizenship and ethnic identity." The author highlights an important insight that "the problem of positive consonance between the civil and ethnic identity stumbles upon overcoming the isolationist ethnic prejudices. ...We keep witnessing the sore ethnic isolationism in the modem civil identity of Russians" (Drobizheva, 2008, pp. 225-226). One of the outbursts arising out of this sore ethnic isolationism is Evenkia's struggle for its special status.

Shnirelman (2000) and Mitroshenkov (2016) look into contemporary ways of managing ethnic identity issues. The former states that contemporary ethnopolitical processes often derive from a mythology of the historic past, and that "ethnocentric versions of the past are being made and used by everyone-those who face disintegration and those who crave segregation into a new unity. All the same, every ethnic group interprets the past in the light of its tangible immediate ethnopolitical interests" (Shnirelman, 2000, p. 18). Mitroshenkov (2016) on the other hand analyzes the role of information and network wars in identity management. Yury Slezkine's 1994 book Arctic Mirrors: Russia and the Small Peoples of the North, provides the historical context of Siberian colonization. He describes the hopes cherished by the well-educated indigenous elite that the reconstruction period might give them an opportunity to play an intermediary role between the political power of Moscow and the "small peoples" in developing full-scale administrative territorial districts for each of the ethnic groups residing in Russia. However, the native peoples of the North remain a minority even in their native territories, and their unique culture appears to be particularly vulnerable in the face of global transformations (Ilbeykina, Kolesnik, Libakova, Sertakova, \& Sitnikova, 2015; Kistova, Reznikova, Zamaraeva, \& Pimenova, 2014; Koptseva \& Kirko, 2014a, 2014b; Koptseva \& Reznikova, 2015).

There are scientific studies on political separatism in Siberia: for instance, Baklulina (2015) researches the issue of Siberian regionalism and its rise in political journalism at the turn of the 21st century; Levochkina (2016) uses the Tyumen, Tomsk, Sverdlovsk Regions, and the Krasnodar Krai as examples of regional identity developed upon the initiative of the local authority, but which is unrelated to ethnic identity. Multiple identities, political competition, relations of the native peoples with the energy companies in Western Siberia and Yakutia are all subjects studied by Balzer (2006), Akishin (2016) on the other hand explores the historical genesis of concepts that have been used to define the legal status of the peoples of Siberia and the Far East. The indigenous minorities of the North are elaborately studied in terms of legal issues in the work of Kryazhkov $(2010,2012$, 2015b); with a special emphasis on Russian legislation of the 1990s and 2000s that concerns the native peoples. Most notably, Kryazhkov (2012, p. 30) points out the "outrageous denial of rights experienced by the small indigenous peoples of the North" brought about by the affiliation of the ethnic autonomous districts (including Evenkia) to the larger regions.

Table 1. Population Dynamics of Indigenous Peoples in the Krasnoyarsk Krai (According to 
the National Census 2002 and 2010)

\begin{tabular}{cccc}
\hline $\begin{array}{c}\text { Ethnic } \\
\text { Groups }\end{array}$ & $\begin{array}{c}\text { Population } \\
\text { to Census 2002 }\end{array}$ & $\begin{array}{c}\text { According } \\
\text { According }\end{array}$ to & Census \\
\hline Nenets & 3,188 & 3,633 \\
Evenks & 4.632 & 4.373 \\
Nganasan & 811 & 807 \\
Selkups & 412 & 281 \\
Dolgans & 5.805 & 5.810 \\
Kets & 1.189 & 957 \\
Entsi & 213 & 221 \\
Chulyms & 159 & 147 \\
Yakuts & 1.368 & 1.468 \\
Khakases & 4,489 & 4.102 \\
Shor & 201 & 161 \\
Nogai & 380 & 950 \\
Tuvan & 1,492 & 2,939 \\
\hline
\end{tabular}

Source: Koptseva and Kirko (2014b).

Shnirelman (2000) recalls the situation of the Itelmen who, like the Evenks, have been pursuing the goal of obtaining preferential treatment from the government due to the peculiarity of its ethnic situation. During the mid-1990s, the Itelmen announced an indemnification claim for the damages they suffered during the Russian colonization of Kamchatka. Kryazhkov (2015a) presents a detailed analysis of the constitutional and legal status of the Finno-Ugric peoples in different territorial units of the Russian Federation. Kim, Shabaev, and Istomin (2015) look into the struggle of the Komi-Izhemtsy for the status of a small indigenous people of the North and definition of the Izhemsky District as a national one, taking a special interest in how the Komi-Izhemtsy reveal the processes of identity and reidentification which are called "identity swings."

Following from the literature, the current study was conducted between 2010 and 2015 through field research in Central Siberia's indigenous settlements situated in Krasnoyarsk Krai and the Sakha Republic (Yakutia) and populated by indigenous peoples of Siberia and the North. Our research was focused on modem ethnic, cultural, political, and economic processes characteristic of the Evenk people, the Selkups, the Nenets, the Chulyms, and the Nganasans. This field research prompted us to do a thorough study of modem ethnic identification processes found among Central Siberia's indigenous peoples, where we discovered that there were quite complex processes ongoing that were heavily affected by global transformation, urbanization, and market economy formation, which is typical of post-Soviet Russia.

Our research was based on expert interviews with a number of representatives of today's indigenous elites who hold some of the key seats in federal, regional, and municipal governments (Table 1) (Koptseva \& Kirko, 2014c; Liba- kova \& Sertakova, 2015). We met with and spoke to nomadic reindeer herders in the settlement of Surinda in Evenk District, interviewed hunters and fishermen in the settlements of Khatanga, Nosok, and Karaul in Taymyr, as well as in the village of Pasechnoye in the Tyukhtetsky District (Koptseva \& Reznikova, 2015). We studied statistical data and other reports filed by the authorities of the Northern indigenous settlements. We conducted expert interviews with state officials working on issues such as government support for Krasnoyarsk Krai's indigenous peoples. The research also involved content from social media and Web sites of nongovernmental organizations.

Following six years of field research, the authors were able to collect vast amounts of material allowing us to build an understanding of certain postcolonial processes that largely define political life in today's Krasnoyarsk Krai, one of Russia's Northern and Arctic regions.

\section{Consolidation of the Elite of Native Peoples of the North and Siberia}

In the 28 administrative units of the Russian Federation, there are over 40 indigenous ethnic and cultural groups currently residing in the North and in Siberia. These modern-day native peoples are going through internal processes of social, economic and cultural disintegration, which is a topic of many studies by Kozlova, Kozlov, and Shilov (2011), Haramzin and Hairullina (2002), and 
Kosheleva $(2003,2005)$.

The consolidation of the local indigenous elite comprising the educated aborigines took place in the 1990s and within the first decade of the 21 st century, through the process of establishment of public associations following the post- Soviet systemic crisis. These ethnic associations were lobbied by the business elites of Russian-Ukrainian and indigenous origin, as well as by the creative elite composed of writers, composers, and the like. All the administrative units of the Russian Federation whose population contains native peoples of the North and Siberia proved to have undergone the same stages in establishing ethnic associations as their only platforms for indigenous people to claim their political rights.

The first stage, referred to here as ethnic mobilization, involves the organizational formation of public movements of the native peoples of the North. In the late 1980s and early 1990s, these took shape as cultural and educational communities. During that period, the ethnic organizations were trying to find their niche in the sociopolitical life of their respective areas and regions, aspiring to become the voice of all indigenous peoples in the political arena.

The second stage of the development of such movements began at the end of 1990-1992 and was characterized by the desire to strengthen the associations' influence over the local authorities. It was at the beginning of this second stage that radicalism peaked, giving way to a growth in negative attitudes of the public toward those movements. In the meantime, the activists of various ethnic movements were announcing such demands as "sovereignty to Gornaya Shoriya," "hand over the oil fields to the native peoples," among others.

The third stage evolved around the years 1993-1994 and was marked by the hasty disappearance of the most radical battle cries from ethnic community documents, followed by an upturn in conformist attitudes among their executives. This resulted from the pressure from local authorities' growing counteractions against separatist trends in the associations' activities.

The fourth stage evolved around the years 1995-1999. The major focus of national politics changed in connection with issues of political reform. Ethnic communities saw in the new directions the possibility of raising new economic demands and protecting their rights to their traditional way of life. During this period, ethnic communities began to understand that their future existence was particularly connected to active political protection of rights to the lands on which their ancestors lived in previous centuries and where their families live at present. Radical ethnic nationalism declined. Political activities instead turned toward the socioeconomic sphere. Within the ethnic associations, the attention of the members shifted more and more to pragmatic aspirations, including dialogue with the local authorities about the socioeconomic issues of the small native peoples of the North. Some representatives of the Northern indigenous people associations were able to penetrate the local power structures.

The fifth stage has been evolving since 1999, as the associations underwent professionalization of their activities. The gap between "those at the helm" and "those at the grassroots" had become wider. The associations were no longer attractive to local authorities in the Tomsk and Kemerovo regions, and only one association managed to keep the support of the Krasnoyarsk government, which abandoned all the alternative ones. Applications for grant aid and funds from nongovernmental organizations became the main activities of the associations during the first decade of the 21st century.

By then, those who represented the elite and who had been standing at the beginning of the revival of interest on the indigenous peoples had turned into government officials occupying senior posts not only in the associations but also in the state power bodies. Associations themselves have evolved a whole new generation of managers, in most cases young people of 20-30 years of age, some of whom had recently obtained their degrees. Representatives of this social group became the locomotives of ethnic cultural revival. In particular, the social group of the "professional" Evenk people, Selkups, Hunts, and Shoria people represented all of the small peoples residing in the region and began to present the activities of the associations as one combined interest which unites all native peoples.

Another area of active involvement of the associations was in the native peoples' lives, 
where the heads of elementary cells in the associations (both rural and regional) dealt directly with practical issues such as striving for better socioeconomic conditions of the native peoples. You then had an ethnic intelligentsia struggling selflessly for the values of their native culture, joining hands with enthusiasts and proponents of the economic revival of the peoples of the North and Siberia.

Ethnic movements were joined by a new group of participants - representatives of the small native peoples of the North who did not sympathize with the beliefs shared by the associations' executives. They tend to espouse radical ideas concerning the return of the traditionally exploited lands to exclusive private ownership of the indigenous peoples, as well as the formation of ethnic autonomous districts or republics in the territories of their residence. These ethnic movement developments show some variation in approach, and their weight and impact upon political processes in the regions also vary.

The most successful example of this has been the Khanty-Mansi District association called "Spaseniye Yugry" (translated into English as Saving Yugra). There are four aspects in its work: that of legislative, economic, ecological, and spiritual revival. Because of the association's activities, the district was the first in the Russian Federation to adopt a law on tribal lands. The Khanty-Mansi District is thus a trendsetter among other Russian administrative units, especially in the number of executive directives issued regarding the situation of the small native peoples. Out of more than a thousand regulatory documents of this sort in Russia, about 260 had been developed in the Khanty-Mansi District alone. The status of the small native peoples of the North has been institutionalized in the main legal act - the Statute of the District. An Assembly for the indigenous peoples' representatives was created to represent their interests in the local Duma. The Chair of this Assembly is then designated as one of the deputy chairs of the Duma. A new form of local government has been successfully developed and so have mechanisms for relations between the administrative units that operate business activities within the territories of the small native peoples.

Things look a little less promising for the small peoples of the North Tomsk and Kemerovo regions in terms of legitimization of their rights at the local government level. However, if the Kemerovo Region has adopted the laws "On the Legal Status of the Small Native Peoples of the Kemerovo Region" and "On Allotment, Use and Protection of Lands of Traditional Use in the Kemerovo Region," the Tomsk Region still has not passed a single regional law that would guarantee the right of the small peoples of the North. The law "On Territories of Traditional Use of the Small Native Peoples of the North in the Tomsk Region" has been discussed and developed for years, but with zero results. Oil companies of other regions make additional financial contributions to indigenous peoples, thus compensating for the damage that they cause to indigenous peoples by extracting oil and gas on the territories, that have initially and for many centuries belonged to indigenous peoples. Only one out of three ethnic rural administrations of the Kemerovo RegionChuvashia-receives deductions from its budget from the subsoil users. On the other hand, the Tomsk region has not yet seen such deductions at all. Relations between the indigenous peoples of the North of the Tomsk Region and oil companies are virtually nonexistent. The greater part of activities undertaken by the associations of the small peoples of the North in the Tomsk Region (Central Siberia) is related to the revival of the native languages and other traditional elements of their cultures.

The economic downturn, ecological problems, deterioration and shrinkage of the traditional habitats, growing unemployment, and scarcity of regular medical care, have only further aggravated the situation of the aboriginal population of the northern territories by exposing them to the threat of physical extinction. Awareness of the dramatic consequences of the current state of affairs gives rise to a feeling of deprivation and despair among the native peoples and, as a result, there have been negative outbursts in interethnic relations, which can lead to destabilization in some of the Siberian regions.

In many northern regions, however, some regional social organizations have firmer standing and their leaders are striving to further strengthen them by running for elective positions in the local political departments. Some examples are N. Pechenina, a Shor woman, who is an elected official in the Kemerovo Oblast Duma, or T. Gogoleva and E. Aipin, members of the Assembly of the Small 
Native Peoples of the North of the Khanty-Mansi Autonomous District Duma.

The biggest social achievement of these movements appears to be the revaluation of the attitude of representatives of the native peoples toward their own ethnicity by overcoming the stereotypes inherited from the Soviet times. At the present time, the process of shifting from negative native ethnic identity to more positive native identity is evident.

The native people's associations appeared to be on the rebound from their situation in the 1980-1990s, and this has led to increased awareness among the native peoples themselves of their self-containment and distinctiveness. This also encouraged the development of skills in political leadership and communication with the government on the basis of partnerships, transforming the mindsets of these ethnic groups such that it is now more prestigious to be a native in one's land of origin; it has become a matter of dignity and pride to belong to one's people and culture.

\section{Evenkia's "Special Status" Movement}

The political struggle currently waged by the Northern and Siberian indigenous elites residing in Krasnoyarsk Krai raises one question: is this political struggle only a cover-up for redistributing state subsidies and other forms of government support (both federal and regional) for Krasnoyarsk Krai's indigenous peoples, or is it an endurance and political shrewdness test for the political elites' loyalty to the federal authorities?

Each and every event related to the discussion of Evenkia's "special status" has generated widespread response in the local media. Krasnoyarsk Krai has become an arena for active economic and political forces using vast financial, media, and human resources to push their political agenda under the guise of their ethnic identification.

It is known that the loudest voice in any public discussion regarding Evenkia's "special status" within Krasnoyarsk Krai belongs to Artur Gayulsky, an Evenk businessman managing large market projects in the Evenk Municipal District. His business interests involve fishing (including particularly valuable species) and reindeer, sable, and fox hunting. The Gayulskys currently control the flows of government and charitable financial support for Krasnoyarsk Krai's indigenous peoples and are involved in every big project connected with distributing financial assets in today's Evenkia, whether it be construction, agriculture, energy, commerce or otherwise. It was Artur Gayulsky who sponsored the experts' backing of the need for Evenkia's "special status," and it is Artur Gayulsky who initiated government and nongovernment discussions on Evenkia's "special status" and who himself is the key evangelist speaking in favor of this "special status."

There is another question yet to be answered: are Artur Gayulsky's political activities being done on behalf of all Evenk people in order to distract attention from his own Evenkia-based business projects, or is he really hoping the area will be granted its "special status," which will allow political leaders with indigenous backgrounds to get hold of new political levers to control the redistribution of even larger chunks of government and charitable support? Whatever the answer might be, it is clear that political games remain "games" only until the political forces involved decide it is a good time to realize their political ambition.

\section{Arguments in Favor of Evenkia's "Special Status"}

The political struggle waged by political forces parading their ethnic backgrounds involves a fair amount of strategizing. Among the masterminds behind the arguments in favor of Evenkia's "special status" is Sergey Komaritsyn (also of Evenk background), a well-known Siberian intellectual, historian, ex-official for the Krasnoyarsk Krai Governor Valeriy Zubov, and then Chief Editor of influential local newspaper, Vecherniy Krasnoyarsk. At the moment, Komaritsyn is close to the circle of the Krasnoyarsk Krai Legislative Assembly Speaker, Alexander Uss, and every now and then is commissioned by Uss to produce expert analysis papers on various issues faced by the Krai. It is Sergey Komaritsyn whom Krasnoyarsk Krai has delegated to be its expert in ranking the most politically weighted governors in today's Russia. He is also a lecturer in United Russia's party school in Krasnoyarsk Krai. His own political preferences lie in supporting the local moderate opposition. At the latest Krasnoyarsk Krai elections for governor, Komaritsyn supported a Russian Communist Party candidate, Valeriy Sergienko, who represented the majority of Krasnoyarsk Krai's farmers. It is known that currently Sergey Komaritsyn is one of the initiators of creating a new 
political party in Krasnoyarsk Krai, the Rural Revival Party, which has already won local elections in Krasnoyarsk Krai's Uzhursk District where it left United Russia far behind. Another thing to add to Sergey Komaritsyn's profile is that he is a Buryat Buddhist and believes that the Northern and Siberian indigenous peoples should unite around Buddhism rather than the Russian Orthodox Church (for more about the role of the Russian Orthodox Church in the Siberia, see Friesen, 2015).

Summing up, Segey Komaritsyn, a well-known local expert and political figure, is the man behind certain regional political forces arguing for Evenkia's "special status." Let us take a look at the main categories of these arguments:

Historical arguments connected with the characteristic features of Russian colonization of the Siberian areas inhabited by the Evenk people;

Cultural arguments related to the Evenk people's need for their own national, administrative, and territorial space for preserving their native language and culture;

Legal arguments related to the legal vehicles enabling indigenous peoples to exercise their rights to their native habitats;

Political arguments centered around reminding people of the promises given by Evenkia's administration leaders when Krasnoyarsk Krai was merged with two other areas 10 years ago;

International arguments related to international documents defending special rights for Northern and Siberian indigenous peoples worldwide.

\section{Looking Back at the Joining of Siberia with Russia}

The foremost argument used by the supporters of Evenkia's "special status" within Krasnoyarsk Krai is that the Evenk ethnic group was autochthonous to the territory of today's Krasnoyarsk Krai (for more about cultogenesis of Evenki, see Batashev, 2013). They claim that the Evenk people's historical habitat used to cover more than half of today's Russia, stretching from the Tyumen region in the west to Sakhalin and the Sea of Okhotsk in the east. Countries beyond Russian borders, such as north of Mongolia and China, are also named among those that used to make up the Evenks' native land.

To justify their views regarding the Evenks' far-reaching history, pro "special status" experts refer to toponymy. This involves a number of geographic names found in Krasnoyarsk Krai, including some of its most prominent and symbolic places, such as the Yenisei River ("Ionessi" in the Evenk language), the Biryusa River ("Biryusal"), Taymyr, Turukhan, and all other place names ending in suffixes -ngn, -ra, -kit, -kan, and others. Even the word "Siberia" ("Sibir" in Russian) is viewed as meaning "world," "Earth," and "Universe" in Tungus and Man- chu languages.

The supporters of the "special status" tend to present the history of the Evenk people within Russia as the history of a "state within a state." Their claim is that the Evenks' law, court system, day-to-day life, and internal community relations were not regulated by the Russian government. To back this point of view, they refer to legal provisions banning Siberian governors from executing aborigines, except that these fail to clarify whether Siberian governors were authorized to execute anyone at all.

One document that draws special attention is the 1822 Statute on the Inorodtsy ("Statute on the Natives"), allegedly authored by Mikhail Speransky. Without quoting directly from the Statute, the supporters claim that the document allowed indigenous peoples to be excluded from the empire's legislation and endowed them with special governmental rights. Yet, having read the 1822 Statute, one can conclude that the supporters of the "special status" expect that their opponents will never bother to familiarize themselves with the text of the Statute since the document itself is quite ambiguous when it comes to the principles of governing indigenous Siberian peoples. For example, they were all liable to pay yasak (a form of tax), and particular people from indigenous communities were assigned to collect it. The Statute also made indigenous peoples subject to all criminal laws of the Russian Empire. So, it appears that the supporters of the "special status" are busy creating new political myths and inventing new historical grounds for backing such myths. Not only are they not bothered that other people might read the historical document they refer to and challenge their arguments, they also expect to be dealing with lazy, poorly educated people with no expert or analytical skills who will go out of their way to open this document and read it. 
Another historical legal document referred to by "special status" advocates is the 1892 Provision of the Russian Empire on Inorodtsy ("Provision on the Natives"). The creators of the new political myth that the Russian Empire initially granted a "special status" to the Evenk people and other Siberian indigenous peoples claim that the Provision guaranteed protection and immunity to territories populated by indigenous peoples involved in traditional economic activities. The people this point is addressed to are certainly not expected to ever open and read the 1892 Provision. Otherwise any independently-minded reader of the document would easily find out that the 1892 Provision on Inorodtsy does not guarantee anything of the kind. There are scientifically-backed legal studies into the document, but the supporters of the "special status" for Evenkia must assume that their audience can do without scientific argument and instead needs more political myths allegedly backed by some historical "evidence."

This new political myth does not refer to the entire Russian Empire's Code of Laws on Inorodtsy ("Code of Laws on the Natives"), but only focuses on three of them, including the Tsar's 1905 Statement which, according to "special status" advocates, ordered that the Evenk people receive primary education in their native language. In this case, the document referred to as "the Tsar's 1905 Statement" is not even identifiable because no formal details of this so-called "document" were ever disclosed. Either way, this "Statement" is outright forgery: up until the 1930s, the Evenk language did not exist in a written form and hence nobody could have been ordered to use this language for teaching purposes in 1905 (Anderson, 2015; Koptseva \& Kirko, 2014a; Slezkine, 1994).

Nearly all documents regulating the relationship between the government and Northern indigenous peoples in pre-Soviet Russia were little more than registers of indigenous peoples where all ethnic groups were divided into the categories "settled" and "nomadic." The Russian Empire laws required settled indigenous people to pay the same taxes as any other Russian peasants, while nomadic peoples were subject to a special form of tax, yasak, with dedicated provisions regarding the rules of its collection. The Russian Empire offered no rules, privileges or "special tatuses" for areas where Northern and Siberian indigenous peoples had their settlements, and it couldn't have offered them due to its political regime, that is, absolute monarchy where all governing rights remained in the hands of the monarch, that is, the Russian tsar.

To sum up the above, the historical arguments put forward by the supporters of the "special status" for Evenkia have no real ground to stand on.

\section{Arguments Related to the History of the Evenks in the Soviet Union}

The modern-day political mythology of the postcolonial kind feeds not only from the remote days of the Russian Empire, but also from the not-so-remote days of the Soviet rule. Following this trend, the creators of Evenkia's "special status" myth claim that the Soviet Union continued the Russian Empire's policy, including that on the indigenous peoples of Siberia and the North. This claim though is not supported by any evidence. On the contrary, the political format and the administrative and territorial division of the Russian Empire were extremely different from those of the Soviet Union.

The first document referred to by the authors of the "special status" idea is an appeal issued by the All-Russian Central Executive Committee (ARCEC) and the Council of People's Commissars (CPC) of the Russian Soviet Federative Socialist Republic (RSFSR) on August 16th, 1919, addressed to "workers, peasants, native peoples, and working Cossacks of Siberia." Advocates of "special status" claim that this Appeal guaranteed a special political and legal arrangement for all Northern indigenous peoples. The truth is, the Appeal was issued in the thick of some of the most intense stages of the Russian Civil War when A. I. Denikin's army was advancing. It was not a legal but a propaganda document, and the point it was making was that the old state (the Russian Empire) no longer existed, which is why there was no need to obey General Denikin's orders. The Appeal did not and could not have contained any legal safeguards and provisions for any kind of special status.

Another type of historical "evidence" put forward by the creators of the political myth is connected with the history of Russia's administrative and territorial division under Soviet rule. It is 
claimed, for example, that the Yenisei Govemor- ate (which is the old name for Krasnoyarsk Krai) used to practice ethnic self- governance, with clan councils vested with a special Northern indigenous status. What they are referring to is the document called "Provisions on governing aboriginal peoples and tribes of the RSFSR's Far North" approved by the ARCEC on October 25, 1926. This document lists a number of forms of self- governance, such as "Clan Assembly," "Clan Council," "District Aboriginal Court," and "District Aboriginal Executive Committee." Such selfgovernment bodies were indeed created in the 1920s. But as soon as the 1930s they had been replaced with state government bodies. The following national districts ("okrugs") were created in December 1930, 1931, and 1932, respectively: Evenk, Vitimo-Olekminsk, and Okhotsko-Even. There were also nomadic Evenk councils and Evenk settlements.

What really happened in those days was that the Soviet state authorities were busy constructing ethnic identities. Using government levers, they eliminated illiteracy among indigenous peoples; for the first time in history, they created the Evenk writing system; thanks to brilliant Russian scholars and teachers, the Evenk people could now enjoy books and newspapers in their native language and listen to radio shows in Evenk; the first Evenk-born intellectuals began to appear; and various Evenk communities living all over Siberia were able to establish reliable communication channels to keep in touch with each other.

Out of all the national districts, it was only the Evenk National District that remained in the 1930s (as part of Krasnoyarsk Krai). Today's Evenk political elite leaders believe that the center of gravity for the Evenk people is the Trans- baikal area, which is where influential Evenk princes of the Gantimur clan used to be based prior to Soviet times. Although in those days the Evenk National District of Krasnoyarsk Krai was home to no more than $10 \%$ of all Evenk people, there was no other territory containing Evenk ethnonyms in its name.

After 1937, the concept of self-governance was forever wiped from the Soviet legislation, even though the 1936 USSR Constitution did give Northern indigenous peoples the right to conduct court litigation, receive education, and publish books in their native languages. The Soviet government was unmistakably paternalistic toward Northern and Siberian indigenous peoples: aboriginal businesses were exempt from tax; the government provided all-round state support to aborigines' children, including preferential treatment when entering universities and colleges; there was free medical care in place for everyone with an indigenous background. A special Research and Development Institute for Medical Issues in the North was set up in Krasnoyarsk in 1976 as part of the Russian Academy of Medical Sciences.

These and other examples testify to the pronounced government paternalism toward the Evenk people, but they do not suggest that the Evenk National District had a special legal system and special government control bodies. In fact, when the industrial development of Siberia and the North began in the 1980s, the USSR Law "On autonomous regions of the RSFSR" from November 20th, 1980, focused exclusively on indigenous peoples' cultural uniqueness, with special attention to preserving reindeer pastures and recommendations to support the development of ethnic culture, arts, and literature (for more on cultural identity of the northern ethnic groups, see Koptseva \& Kirko, 2014a; Libakova, Sitnikova, Sertakova, Kolesnik, \& Ilbeykina, 2014; Peers, 2015; Reznikova, Zamaraeva, Kistova, Anastasia, \& Pimenova, 2014).

The demographic and cultural disproportion is still there for the Evenk people though. The absolute majority of the Evenk people, which is 21,008 people, live in the Sakha Republic (Yakutia) rather than the Evenk Municipal District of Krasnoyarsk Krai. According to the 2010 Russian Census, only 4,632 Evenks lived in Krasnoyarsk Krai, which is no more than 5\% of the total number of Evenks living in Russia, Mongolia, and China. This means that the historical trends and the legal documents referred to by the supporters of the political myth about Evenkia's all-time "special status" fail to offer a single piece of reliable proof. Contrary to these people's claims, the Evenk Municipal District within Krasnoyarsk Krai is nowhere near a demographic, economic, and cultural center for the Evenk people worldwide. Most likely, the ethnonym "Evenk" remains in the area's name only due to certain political and geographic inertia. No more than 1,000 people living in the Evenk Municipal District are currently involved in traditional economic activities, but experts 
believe that even this number is likely to be grossly exaggerated.

\section{Political Arguments Connected with the Promises Made to Evenkia's and Taymyr's Indigenous Elites When Uniting Krasnoyarsk Krai, Evenkia, and Taymyr in 2005}

When making passionate speeches during conferences, roundtable discussions, seminars, and at the Krasnoyarsk Krai Legislative Assembly sessions, people representing modem Evenkia's ethnic elite never fail to make reproachful comments and complain that certain political agreements between federal and local Krasnoyarsk Krai authorities and Evenkia's ethnic elites were allegedly ignored. Their opponents from local authorities insist on the opposite and claim that such political agreements were kept in full. Expert analysis of the current economic and political space of Krasnoyarsk Krai suggests that the promises given by the Krai's political elite (i.e., the team of exGovemor and currently one of Russia's Deputy Prime Ministers, Alexander Khloponin) were largely honored.

In 2015 there were 15,425 residents living in the Evenk Municipal District, which is $0.5 \%$ of Krasnoyarsk Krai's total population. The population of the Even- kiysky Municipal District does not only comprise the nationality of Evenks. Of the 15,425 residents, three-quarters are Russian. The native population - Evenks - belong to the Paleo-Siberian language group. They comprise no more than $14 \%$ of the total population of the district, which amounts to 2,400 people.

The rest of the Evenks (approximately 2,260 people) of the Krasnoyarsk Krai live in other areas: Taymyr, Turukhansk, or the Yeniseysk regions. But out of the 65 Krasnoyarsk Krai Legislative Assembly Members of Parliament (MPs), two represent the Evenk Municipal District, whereas other areas (except Taymyr) are represented by only one MP each. In other words, Evenkia's MPs make up 3\% of the Krasnoyarsk Krai Legislative Assembly. This means that the 15,425 Evenks living in the area are represented by two MPs, while the 153,112 people living in the Oktyabrsky District of Krasnoyarsk are represented by a single MP.

And so the two MPs from the underpopulated Evenkia appear to be part of that very "special status" which is in the center of today's political and information war raging in Krasnoyarsk Krai. Experts believe that this preferential representation of the Evenk Municipal District in Krasnoyarsk Krai's legislative bodies is one of the points of the agreement once made between the local elites and the team of then Governor Alexander Khloponin. Indirectly speaking in favor of this assumption is the fact that for 10 years, one of the MPs representing Evenkia in the Krasnoyarsk Krai Legislative Assembly has been Anatoliy Amosov who used to be the Chairman of Suglan (Evenkia's Legislative Assembly) in the days when Evenkia was a separate subject of the Russian Federation and was about to be merged with Krasnoyarsk Krai. At the moment Anatoliy Amosov is the Chairman of the North and Indigenous Minorities Committee at the Krasnoyarsk Krai Legislative Assembly. Experts informed on the issue believe that Anatoliy Amosov does not belong to any specific clan of the Krasnoyarsk Evenks, and hence his very presence in the area's legislative body is likely to be a middle-ground decision reached as a result of an agreement between the team of ex-Governor Alexander Khloponin and the formal leaders of Evenkia prior to the area's merger with Krasnoyarsk Krai.

The real political leaders of the Krasnoyarsk Krai Evenks are the Gayulsky brothers, Viktor and Arthur. They are descended from prince Gantimur who in the 16th century signed a treaty with grand prince of Moscow Ivan IV the Terrible in reference to the border control between the Grand Principality of Moscow and the Chinese state units. Viktor Gayulsky was a member of the first and second State Duma of the Russian Federation between 1993-1995 and 1995-1999. He was also a long-time owner of the deer-breeding farm "Surinda" and worked as an advisor to the Governor of the Krasnoyarsk Krai when the position was held by Lev Kuznetsov (2013-2014). At the present time, Viktor Gayulsky is the Chair of the Evenk Union of Russia. He never misses a single event related to the minority indigenous peoples of the Krasnoyarsk Krai and consistently represents their interests at all levels of the regional and federal government.

Equally notable in political activities in the Krasnoyarsk Krai is his brother, entrepreneur Arthur Gayulsky who between 2011-2012 was in fact competing for the membership in the Krasnoyarsk Krai Legislative Assembly. According to the official line, he lost by just one vote to 
his rival Ivan Rebrik representing a largest financial industrial group RUSAL whose owner, Oleg Deripaska, is an influential Russian oligarch. Ivan Rebrik, member of the United Russia political party, received 1,415 votes, whereas Arthur Gayulsky, representing the Just Russia party and supported by the native peoples of Evenkia, got 1,414 votes. Arthur Gayulsky initiated a number of court cases demanding that the courts look into the matter of the numerous offences that as he claimed had been committed during the electoral campaign. According to the major Russian newspaper Kommersant:

the Court was presented with strong conclusive evidence of large-scale violations in the election. The buses owned by the local oilmen were claimed to have carried students of a local agricultural college to electoral stations where they apparently voted in favour of Ivan Rebrik having been asked to do so by the principal. There were also a number of cases recorded when disabled people and citizens residing outside the Evenk Municipal District voted in large numbers using absentee ballots. The most blatant of all appeared to be the case when the ballot cast in favour of Mr. Gayulsky was declared void by the District Election Commission of the Yessey village due to some insignificant tears that were asserted not to 'have impaired the legibility of the ballot so as to see who the vote had been cast for.' According to Arthur Gayulsky, 'everything that occurs cannot be called anything but' 'rampant lawlessness' advocated by the ruling party and some particular business corporations, (http://www. kommersant.ru/ doc /1892625)

Another political leader supporting the interests of the indigenous peoples in their struggle for ethnic identity is Semyon Palchin, small indigenous peoples rights ombudsman of the Krasnoyarsk Krai. He is enlisted in the administrative office of the Human Rights Ombudsman of the Krasnoyarsk Krai. Semyon Palchin prepares an annual report on how the rights of the indigenous peoples are observed in the Krasnoyarsk Krai. The report is always discussed at the Krasnoyarsk Krai Legislative Assembly and published on the Web site of the Human Rights Ombudsman of the Krasnoyarsk Krai (http://ombudsmankk.ru/doc. php?id = 719).

Semyon Palchin is an active proponent of the idea of giving Evenkia a special status as part of the Krasnoyarsk Krai. In his report on the state of the native peoples rights for the year of 2014, he quoted a notable example showing which economic measures in particular violate their rights to the ancient ancestral lands.

The tribal community of peoples of the North "Yambukan" (which translates as 'fullflowing') from the Evenk Municipal District made a decision to reserve, on a leasehold basis, their right to the ancestral territories. On request and at the expense of the community, all the necessary procedures on defining and describing the borders and characteristics of a relevant patch of land stretching over the area of 237,280 ha. were performed. At the auction was clearly stated that it was designated for northern deer breeding farming. However, alongside the bid from the community there was another bid from Drofa, LLC, Samara Region. As a result, the winning bid of the Drofa company totaled 5 million roubles out of the bid with initial price of 12,000 roubles. Thus, the ancestral lands of the indigenous peoples fell into the hands of those who have never lived in the North or Siberia and are not in fact, indigenous peoples. Moreover, the local tribal communities ended up losing vast patches of land.

Thanks to his annual reports publicly disclosing particular events of violation of the indigenous peoples rights, Semyon Palchin occupies a prominent position in their elite and is viewed by the native peoples of the Krasnoyarsk Krai as one of the leaders in the struggle for their ethnic identity and political presence in the Krasnoyarsk Krai government structure.

Regardless, the contemporary movement for the rights of indigenous peoples of modernday, Russia is restricted by the fact that currently the appurtenance of this or another person to the indigenous people does not have a legal status.

Another example of keeping political promises is related to the unprecedented scale of direct or indirect government support provided to the indigenous peoples of Krasnoyarsk Krai by local executive authorities. In terms of direct measures, all Evenkia's reindeer herders receive 400 rubles per reindeer per annum in state subsidies. Interestingly, there are no reliable figures in terms of the exact number of reindeer herded by the Evenks. The figures used for calculating the amount to be 
paid out in state subsidies are quite arbitrary. Microchipping reindeer in Evenkia never happened, and it is Evenk businessmen who keep opposing it under all kinds of pretexts (Zamarayeva, Kistova, Pimenova, Reznikova, \& Seredkina, 2015). The amount of the state subsidy for keeping domesticated reindeer is also poorly justified.

Experts believe that financial asset distribution in Evenkia is corrupt and controlled by the members of influential ethnic clans holding official seats. While we were out on our field research in the settlement of Nosok (Taymyr), some respondents told us that government subsidies for domesticated reindeer herders start from 400,000 rubles per family per annum and Nenets reindeer herders often visit the settlement only to collect the money and continue nomadic life in the tundra.

Respondents reported that, the biggest financial resources are concentrated in the hands of the indigenous political elite who prevent the calculation of the exact number of reindeer held by each indigenous family. Experts estimate that the real number of herded reindeer is two to three times smaller than the figures declared by the same mythological reindeer herders who control the distribution of government subsidies and count the reindeer that these subsidies are supposed to be paid for. The head of one of the northmost local settlements reportedly currently owns 11 apartments in various Russian cities, including Sochi where property prices are well above the national average. Needless to say, some of the corrupt officials in control of distributing government subsidies are "professional aborigines" who are supposed to protect the rights of indigenous peoples against unnecessary interference from government authorities. By blackmailing government officials with revelations on infringing aborigines' rights, these political figures and community leaders only reveal themselves as corrupt individuals who have "privatized" the very state segment which is supposed to help their fellow countrymen.

One can even assume that Evenkia's political elites see these locally-controlled subsidies for domesticated reindeer as a kind of a reverse tax, which is no longer paid by themselves, but by the government so as to purchase a certain level of political stability at its Northern borders.

A similarly complex situation is found with quotas for catching particularly valuable varieties of fish for the indigenous peoples living in Krasnoyarsk Krai and for everyone else living in the northern parts of the area. Current regulations allow catching two tons of fish per person per annum, with no additional criteria specified for those who can benefit from these quotas. This means that each person residing in Taymyr, Evenkia, and the Turukhan District is allowed to catch two tons of fish per annum with no licensing and no sales tax. Basic common sense suggests that two tons of fish per annum for one person or six tons of fish per annum for a small family of three is substantially more than the amount of fish consumed by an average person. Clearly, this is about fishing on a commercial scale. Yet the government is not receiving any tax on these fish sales, while the profit all goes to line the pockets of the ethnic elite who use their status to manipulate the government's fishing quotas and their implementation in the northern areas of Krasnoyarsk Krai. Additionally, there are no rules specifying which Krasnoyarsk Krai residents qualify as indigenous minorities and which do not.

Well-known Russian ethnographer Victor Krivonogov specializes in demographic processes in Krasnoyarsk Krai's indigenous peoples, and says there is active assimilation under way in indigenous populations. Most indigenous individuals today are of mixed origin, with the share of the Evenk ethnic group being 50\% or less. Nowadays Russian law does not offer any legal tools for identifying a person's ethnicity other than by relying on their ethnic self- identification. Some experts believe that ethnic identification among today's indigenous peoples of Siberia and the North is predetermined by the very privileges given to these indigenous peoples by the state: subsidies for traditional economic activities, partly covered tuition fees, lower retirement age, and others. Had there been no government support for Northern and Siberian indigenous peoples, in 10 to 15 years' time ethnic assimilation would entirely dilute their presence in the modem urban population of the Siberian regions (Koptseva \& Kirko, 2014b).

The weak government control over the distribution and the payment of state benefits and the economic advantages given to today's Northern indigenous peoples living in Krasnoayrsk Krai may suggest that some members of the Northern indigenous elites see these advantages as a result for 
their agreement to merge Krasnoyarsk Krai with Evenkia and Taymyr in 2005. Evenkia's journey as a separate subject of the Russian Federation was a short one and lasted only 15 years, from 1991 to 2006. But, once prompted by the merger, the indigenous political elites never stopped to receive ongoing paternalistic, economic, and political support from the government as a ransom for their agreement to go ahead with the joining and give up the status of a separate subject of the Russian Federation (Koptseva \& Kirko, 2015).

Speaking in support of the indigenous political elite of Siberia and the North, V. A. Kryazhkov argues that when Evenkia, Taymyr, and Krasnoyarsk Krai were merged together, "indigenous peoples were stripped of their legislative and other government bodies and lost their direct representation in the Russian Parliament alongside any direct and other links with the federal authorities. This substantially reduced the guarantee of indigenous peoples' social and other rights" (Kryazhkov, 2013, p. 141).

\section{References to China's Approach to Managing the Evenks}

Some of the most brilliant examples of the political mythology justifying the Evenk people's "special status" in other regions and countries is connected with the People's Republic of China and its approach to the Evenks. The indigenous political elite have long been painting China as the promised land for all Russian Evenks. When speaking at political events and in traditional or social media, the political leaders of Krasnoyarsk Krai's indigenous peoples regularly refer to the standard of living and the quality of life enjoyed by the Evenk people residing in the Evenk Autonomous Banner (Ewenkezii Zizluqi) in China. Interestingly, while the Russian name of the area (Эвенкийский автономный хошун) includes the word "autonomous," the original Chinese name makes no mention of this word.

China's ethnic policy is quite well-researched, and all studies agree on the following: these days the key privileges in China's party and state management belong to people from the Han ethnic group. For example, the 17th Politburo of the Communist Party of China included only one nonHan woman, Liu Yandong, and only one non-Han member, Hui Liangyu. The current, 18th Politburo of the CPC, features a very similar composition.

Domestic policies in regard to non-Han ethnic groups are an extremely sensitive issue for today's China. One of the biggest worries for China's political leadership is that the country might split into several independent ethnic states the way the Soviet Union once did. Despite including five autonomous regions with ethnic references in their names, today's China is not a federation in the true sense of the word. One of the things that China started doing to ease its interethnic tensions was increasing the number of people representing ethnic minority elites in its political establishment. For the first time in the People's Republic of China (PRC)'s history, all its five autonomous regions (the Tibet Autonomous Region, XUAR, the Inner Mongolia Autonomous Region, the Ningxia Hui Autonomous Region, and the Guangxi Zhuang Autonomous Region) are governed by people with ethnic minority backgrounds. At the same time, having placed ethnic minority officials into the key seats in the country's ethnic regions, to keep its grip on these areas, the CPC also appointed Han people to the most crucial political roles, that is, those of Party Secretaries.

Looking at the status of ethnic leaders in China, particularly in its autonomous regions, one can get a better idea of the dilemmas faced by the PRC's leadership on the interethnic front. While China's authorities are forced to give way to more non-Han leaders in order to keep up with their state ethnic policies and demonstrate their commitment to positive action to the public, they also want to be sure that Han leaders can maintain their key positions in the government.

One important change related to promoting ethnic minority leaders happened in the legal field. For example, in 2002, the National People's Congress of China revised the Law on Ethnic Minority Autonomous Regions in the PRC. The revised law now requires that the highest office in the local authorities of all the country's autonomous regions be held by a leader representing the same ethnic group as the majority of citizens residing in the region. According to an official Chinese source, at the moment, all the 155 ethnic minority autonomous areas in China, including five provincial-level autonomous regions (ZizluqU), 30 prefectures (Zizliizhdu), and 120 counties 
(Zizliixian and Zizluqi), are headed by non-Han officials. The Head of Local Administration is often considered to be the second most important and influential role in an area after Party Secretary.

Having looked into the ethnic backgrounds of China's provincial and municipal leaders and heads of nongovernmental organizations, we did not find a single Evenk person among them. This is only in line with China's law requiring that such leaders should represent the ethnic majority in their administrative area. The Evenks do not make up the majority in any area of China. Their total population in the country is currently 5,000 people. On January 23rd, 2013, the Chinese newspaper Huanqiii Slubao (Global Times) published an article with a tell-tale headline, "You can't carbon copy Soviet ethnic policy" (http://inosmi. ru / world /20130123/204974865.html). The author of this article. Professor $\mathrm{Wu} \mathrm{Chu} \mathrm{Ke}$ of the Central University for Nationalities, talks about the key principle behind China's ethnic policy today: ".. .Given the big picture, prioritize uniformity and reduce any preferential treatment." Interestingly, $\mathrm{Wu} \mathrm{Chu} \mathrm{Ke}$ uses the Evenk people as an example demonstrating the idea that various ethnic groups simply cannot be equal in modem China: "For example, equality is hard to achieve because changing the factually unequal positions of a billion Han people and 5,000 Evenks appears to be impossible. The principle needs to include one provision: ethnic minority areas and other parts of the country must be viewed as one; everyone must be treated equally, and none of the parties must enjoy special treatment; discrimination must not be allowed, and preferential treatment must be reduced."

Summing up the above, the author of the article talks about modern China's political leadership planning to substantially reduce the privileges given to ethnic minorities, speaking of the Evenks as an example. Proper Evenk sovereignty in China is out of the question: their share is too small even for an ethnic minority. Even in the Evenk Autonomous Banner the Evenks make up only $6.6 \%$ of the population. Otherwise the majority are Han $(61.15 \%)$, followed by Mongols (18.74\%) and the Daurs $(9.5 \%)$. Despite the area being named after them, the Evenks are only the fourth biggest ethnic group living there.

Krasnoyarsk Evenks retained contacts with Chinese Evenks, while some families from the Evenk elite sent their children to Chinese universities. But a closer look at the Evenks' life in China resulted in a real disappointment: it turned out that Chinese Evenks currently have no rights to practice their traditional economic activities, such as hunting and fishing. Reindeer farming and ethnic crafts have survived only in special ethnic villages where the Evenks look a sad sight as "museum pieces" pretending to be "ancient Chinese nomads" for money. An ethnic group transformed into "museum pieces," with no right to hunt and fish, no proper writing system, literature or developed culture-all this disappointed most of the Evenk political elite based in Krasnoyarsk. But they hide their disappointment carefully, and when some experts or political leaders mention China as the "promised land" for all Evenks worldwide, the Krasnoyarsk-based Evenk leaders keep quiet. For them, having no right to hunt and fish means having no life, which is unacceptable.

\section{Conclusions}

At the moment, Krasnoyarsk Krai's indigenous peoples are a motley mix of communities whose heterogeneity comes from the irregular ways in which modernization affected these autochtonous populations, particularly in the 20th and the beginning of the 21st century, that is, from the diversity of mechanisms applied by these ethnic groups to cope with the cultural trauma. These peoples are in danger of disappearing for demographic reasons, or because of continuous assimilation, or as a result of a change of ethnic identity or by adopting a "dual" identity (Koptseva \& Kirko, 2014b).

Postcolonial processes found in Central Siberia have their unique features and vary from one indigenous group to another. Ethnic identification processes among the Central Siberian Evenks were on the rise during the Soviet period. Their ethnic history is connected with a number of transformations, both global and local (i.e., post-Soviet). Their ethnic communities are undergoing active stratification. The Evenks are in the process of creating their political elite who are becoming known as "professional aborigines." This political elite is more likely to include people with mixed 
backgrounds residing in urbanized settlements rather than pure Evenks living a nomadic lifestyle. "Professional aborigines" have clearly identifiable economic interests characteristic of the postSoviet market economy, their political weight is becoming more tangible in Central Siberia. In 2015, at the first reading of the Legislative Assembly, the Krasnoyarsk Krai adopted the Law on "the special status" of the Evenk Municipal District and Taimyr Dolgan-Nenets Municipal District as part of the Krasnoyarsk Krai. This is a significant victory for the political elite of Evenks, which allows them to continue and to strengthen their political pressure on the basic processes in Central Siberia.

\section{References}

Akishin, Michael A. (2016). Ethnic communities in Siberia in the history of Russian law: The problem of definitions. Legal Technique, 10, 60-67 (in Russian).

Aligadzhieva, Madina A. (2016). Criteria for renovation of the political elite in the Republic of Dagestan. Power, 2, 68-71 (in Russian).

Anderson, David. (2015). Russian colonialism and hegemony and Native Siberian languages. Language Empires in Comparative Perspective, 6,113-140.

Anderson, David G. (2006). Is Siberian reindeer herding in crisis? Living with reindeer fifteen years after the end of state socialism. Nomadic Peoples, 10(2), 87-104.

Atnagulov, Irek R. (2015). Social and cultural practices and identities Nagaibaks structure based on 2014-2015, expeditions. Scientific statements Belgorod State University. Series: History. Politics, 19 (36 (216)), 136-144 (in Russian).

Baklunina, Svetlana D. (2015). Siberian regionalism ideas in journalism of the late XX early XXI century. Historical, philosophical, political and legal sciences, cultural studies and art history. Theory and Practice of Tambov: Diploma, 8(58), 34-37.

Balzer, Marjorie M. (2006). The tension between might and rights: Siberians and energy developers in post-socialist binds. Europe - Asia Studies, 58(4), 567-588.

Balzer, Marjorie M. (2015). Siberia: A history of the people. Nationalities Papers, 43(4), 655-657.

Baranov, Andrew B. (2015). Crimean Tatar movement: The trend of conflict and participation in peace-building. Power, 1, 209-212 (in Russian).

Batashev, Mikhail S. (2013). Ethnic history of indigenous peoples of the Yeniseysky Uyezd in the 17th century and their fortunes. Journal of Siberian Federal University. Humanities \& Social Sciences. 6(6), 842-869.

Boeck, Brian J. (1998). The Kuban' Cossack revival (1989-1993): The beginnings of a Cossack national movement in the North Caucasus region. Nationalities Papers, 26(4), 633-657.

Bonifacio, Valentina. (2013). Meeting the generals: A political ontology analysis of the Paraguayan Maskoy struggle for land. Anthropologica, 55(2), 385-397.

Drobizheva, Lyudmila M. (2008). National civil and ethnic identity: Positive compatibility issues. Russia is Reforming, 7-M, 214-228 (in Russian).

Fisher, Eloy. (2014). Constitutional struggle and indigenous resistance in Latin America: The case of Panama. Latin American Perspectives, 41(6), 65-78.

Frake, Charles O. (2014). How to be a tribe in the southern Philippines during the advent of NGOs and the invention of the indigenous. Human Organization, 73(3), 197-204.

Friesen, Aileen. (2015). Building an Orthodox empire: Archpriest Ioann Vostorgov and Russian missionary aspirations in Asia. Canadian Slavonic Papers, 57(1-2), 56-75.

Gribanova, Galina I. (2015). Unrecognized States in the context of restructuring and the collapse of the Soviet Union. Scientific publications of the North-West Management Institute of the Russian Academy of National Economy and Public Administration, 6(21), 15-21 (in Russian).

Haramzin, T. G., \& Hairullina, N. G. (2002). The traditional way of life and way of life of the Ob Ugrians (on materials of sociological research). Moscow: "IKAR" Publishing.

Holmes, Douglas R. (2002). Provincializing Europe: Postcolonial thought and historical difference. American Ethnologist, 29(1), 214-216.

Ilbeykina, Maria I., Kolesnik, Maria A., Libakova, Natalia M., Sertakova, Ekaterina A., \& 
Sitnikova, Alexandra A. (2015). Global and local trends in development of the Siberian city of Krasnoyarsk. Mediterranean Journal of Social Sciences, 6(3 S5), 241-248.

Kholodov, Vladimir G., \& Nuriahmetova, Fljura M. (2015). Model of Tatarstan as an alternative pro- togosudarstva (to the 25th anniversary of statehood of Tatarstan). Kazan Pedagogical Journal, 1 (4). (in Russian).

Kim, Hye Ch., Shabaev, Yu P., \& Istomin, Kirill V. (2015). Local artist in search of identity (Komi Izhemtsy: The dynamics of cultural transformations). Sociological Research, 8(8), 85-92 (in Russian).

Kistova, Anastasia V., Reznikova, Ksenia V., Zamaraeva, Julia S., \& Pimenova, Natalia N. (2014). The current state of traditional socio-cultural practices of indigenous peoples of the North (on the example of cultures of Selkups, Nenets and Essey Yakuts). Life Sciences Journal, 11(12), 126-132.

Koptseva, Natalia P., \& Kirko, Vladimir I. (2014a). Ethic identification of indigenous people of the Siberian Arctic. American Journal of Applied Sciences, 11(9), 1573-1577.

Koptseva, Natalia P., \& Kirko, Vladimir I. (2014b). Specificity of ethnogeny indigenous peoples by central Siberia in the transition from the traditional type of society to modern society. Life Science Journal, 11(8), 409^13.

Koptseva, Natalia P., \& Kirko, Vladimir I. (2014c). The information basis for formation of positive ethnic identities in the process of acculturation of indigenous peoples of the arctic Siberia (Krasnoyarsk, Russia). Life Science Journal, 11(8), 479^83.

Koptseva, Natalia P., \& Kirko, Vladimir I. (2015). The impact of global transformations on the processes of regional and ethnic identity of indigenous peoples Siberian Arctic. Mediterranean Journal of Social Sciences, 6(3 S5), 217-223.

Koptseva, Natalia P., \& Reznikova, Ksenia V. (2015). Clarification of the causes of ethnic migration of northern Selkups based on the historical memory of indigenous ethnic groups in the Turu- khansk District of Krasnoyarsk Krai. Bylye Gody, 38(4), 1028-1038.

Kosheleva, Elena. (2003). Ethnic movements of indigenous peoples of the North West Siberian region, late 20th - early 21 st century. Tomsk: Publishing Tomsk Polytechnic University.

Kosheleva, Elena. (2005). About the benefits for indigenous peoples to higher education in Tomsk Oblast. Bulletin of the Network for Ethnic Monitoring and Early Warning, Publisher Institute of Ethnology and Anthropology named after Nikolay Miklukha-Maclay Academy of Sciences, Moscow, 86-87.

Kozlova, M. A., Kozlov, A. I., \& Shilov, A. B. (2011). Egalitarianism and stratification in the communities of indigenous northerners. Journal of Archaeology, Anthropology and Ethnography, 14(1), 212-218.

Kryazhkov, Vladimir. (2010). Indigenous people in the Russian law. Moscow: Norma.

Kryazhkov, Vladimir. (2012). Russian legislation on northern peoples and practice: State and prospects. The State and the Right, 5, 27-35 (in Russian).

Kryazhkov, Vladimir. (2013). Development of Russian legislation on Northern Indigenous Peoples. Arctic Review on Law and Politics, 2,140-155.

Kryazhkov, Vladimir. (2014). Determination of the status of the Crimean Tatar people in the Russian Federation. Constitutional and Municipal Law, 9, 48-52 (in Russian).

Kryazhkov, Vladimir. (2015a). Constitutional and legal status of the Finno-Ugric peoples in the Russian Federation. Constitutional and Municipal Law, 5, 24-33.

Kryazhkov, Vladimir. (2015b). The legislation on communities of Indigenous Peoples as a developing system. State and Law, 11,49-58.

Levochkina, Natalia A. (2016). Regional identity: The concept and essence. International Journal of Applied and Basic Research, 1,446M53.

Libakova, Natalia M., \& Sertakova, Ekaterina A. (2015). The method of expert interview as an effective research procedure of studying the indigenous peoples of the North. Journal of Siberian Federal University. Humanities \& Social Sciences, 1(8), 114-129.

Libakova, Natalia M., Sitnikova, Alexandra A., Sertakova, Ekaterina A., Kolesnik, Maria 
A., \& Ilbeykina, Maria A. (2014). Interaction of the Yakut

ethnicity and biological systems in the territory of the Sakha Republic (Hordogoy Settlement, Suntarsky District) and Krasnoyarsk Krai (Essey settlement, Evenks District). Life Science Journal, 11(6s), 585-592.

Little, Peter D. (2016). A victory in theory, loss in practice: Struggles for political representation in the Lake Baringo-Bogoria Basin, Kenya. Journal of Eastern African Studies, 10(1), 189-207.

Lobova, Ludmila. (2002). Ethnopolitical conflicts in Northcaucasus in historical dimension National problems or geopolitical challenge for Russia? Orient, 43(1), 59-77.

Lurie, Svetlana. (1999). Nationalism, ethnicity and culture. Social Sciences and Modernity, 4, 101-111 (in Russian).

Lynch, Gabrielle. (2016). What's in a name? The politics of naming ethnic groups in Kenya's Cheran- gany Hills. Journal of Eastern African Studies, 10(1), 208-227.

Magamadov, Sulyan S. (2013). Nodal questions of history of the peoples of the North Caucasus 20- 30 years of the twentieth century: Achievements and issues. Humanitarians of the South of Russia, (4), 145-155.

Makarov, Nikolaj P. (2013). The ancient stages of the culture genesis of the Krasnoyarsk Northern indigenous peoples. Journal of Siberian Federal University. Humanities \& Social Sciences, 6(6), 816- 841.

Mitroshenkov, Oleg A. (2016). Identity: From a theoretical concept to management actions. Power, 2, 14-28 (in Russian).

Peers, Eleanor. (2015). The post-colonial ecology of Siberian Shamanic revivalism. Worldviews: Global Religions, Culture, and Ecologxj, 19(3), 245-264.

Reznikova, Ksenia V. (2013). Preservation and transformation of certain aspects of the traditional way of life of the indigenous and small-numbered peoples of the North, living in the settlements (Posyolki) of Turukhansk and Farkovo. Journal of Siberian Federal University. Humanities \& Social Sciences, 6(6), 925-939.

Reznikova, Ksenia V., Zamaraeva, Julia S., Kistova, Anastasia V., \& Pimenova Natalia N. (2014). The current state of traditional socio-cultural practices of indigenous peoples of the North (on the example of cultures of Selkups, Nenets and Essey Yakuts). Life Science Journal, 11(12), 126-132.

Shirvanova, Tarana. (2013) Ethnic variety in South Caucasus: Conflicts and perspectives. Mediterranean Journal of Social Sciences, 43(1), 59-77.

Shnirelman, Victor A. (2000). The value of the past: Ethnocentric historical myths, identity and ethnic policies. The reality of ethnic myths. Moscow: "Gandalf" (in Russian).

Sirazhudinova, Saida B., \& Galbatsov, Surkhay M. (2016). Ethnopolitical competition and the role of civil society in the sustainable development of the Republic of Dagestan. Power, 2, 149154 (in Russian).

Slezkine, Yurij. (1994). Arctic mirrors: Russia and the small peoples of the North. New York, NY: Sage House.

Srikanth, Hari. (2014). Who in North-east India are indigenous? Economic and Political Weekly, 20, 41- 46.

Stepanov, Valery. (2000). Ethnic tensions and separatism in Russia. Journal of Ethnic and Migration Studies, 26(2), 305-332.

Zamaraeva, Julia S. (2014). What are global transformations experienced by the indigenous peoples of the North? Journal of Siberian Federal University. Humanities \& Social Sciences, 10(7), $1705-1718$.

Zamarayeva, Yulia S., Kistova, Anastasia V., Pimenova, Natalia N., Reznikova, Ksenia V., \& Seredkina, Natalia N. (2015). Taymyr reindeer herding as a branch of the economy and a fundamental social identification practice for indigenous peoples of the Siberian Arctic. Mediterranean Journal of Social Sciences, 6(3 S5), 225-232. 